\title{
ORIENTAL vS. AMERICAN LABOR
}

\author{
By A. E. Yoell,
}

Secretary Asiatic Exclusion League of North America, San Francisco, Cal.

For a proper comprehension of the dangers threatening the wage earning classes in California through the competition of Asiatics it is necessary to take a view of the conditions prevailing in Hawaii, brought about by the predominance of the Asiatic element in the population of that territory. With a population of 170,000 of all races, there are 72,000 Japanese, 25,000 Chinese and about 8,000 Koreans, making the Asiatic element $6 \mathrm{I}$ per cent of the whole.

The orientalization of the Hawaiian Islands and the resulting character of the working population by the elimination of white mechanics and laborers have created an acute labor problem, and the white laborer of California fears that the presence of large numbers of Asiatics in that state will bring about conditions similar to those existing in Hawaii. For the wage earner and small merchant, the problem is one of survival in the face of an increasing, irresistible and disastrous competition.

Less than 50 per cent of these Asiatics are engaged in plantation work, and other agricultural pursuits ; the remainder are in domestic service, trade and transportation, manufacturing and mechanical pursuits. In some of these lines Asiatic competition is of early date, but during the past five or six years every trade has been invaded, in some instanees to the absolute exclusion of the Caucasian element. There are practically no white wage earners engaged in making men's and women's garments and shoes, though a few earn a precarious living by repairing and cobbling. The Japanese are strong competitors in the plumbing trade, and in some places have practically monopolized the work of making tinware for plantation stores, and for sale among working people. The whites are being driven from all the miscellaneous trades very rapidly.

The building trades have also been aggressively invaded by the Japanese, and white mechanics are steadily giving up and forming a procession back to the coast. A white contractor, who used white and Hawaiian labor only, recently said that he had not had a contract (247) 
of any importance for nearly a year and a half, because he had been ruinously underbid, either by Japanese contractors or white contractors using Asiatic labor exclusively. He called attention to a large building being constructed, upon which thirty-five workmen were employed, and although there were plenty of whites and Hawaiians idle, not a single workman was found on the building except Asiatics. Every detail of the building-carpentering, plastering, plumbing, painting-was done by Asiatic labor. The only city occupations not yet subject to keen Japanese competition are the English printing trades and some forms of machinery and metal working.

There is an aspect of the Japanese question in Hawaii which also affects the planters, and it arises out of the preponderance among the laborers of a single nationality, which, to a certain extent, takes out of the hands of owners the control of administration. The Japanese have learned their power and use it unmercifully. Evidence, both direct and indirect, presented itself in 1905, showing that plantation owners fear the power of their Japanese laborers, and endeavor to placate them by concessions not dictated primarily by regard for efficient service. At this writing, June I, 1909, some 10,000 Japanese plantation laborers are on strike for higher wages, and though the planters are, to some extent, filling their places with the labor available, it may safely be predicted that, as half of the sugar crop remains unmilled, the Japanese will win the day.

The wages paid Orientals in Hawaii on the plantations is about one-third of that paid to whites for the same class of employment. In the miscellaneous trades in Honolulu the difference is not so great, being about 50 per cent, but it is in the mechanical and building trades that the keenest competition by means of reduced wages is felt.

\section{Average Wages Per Day.}

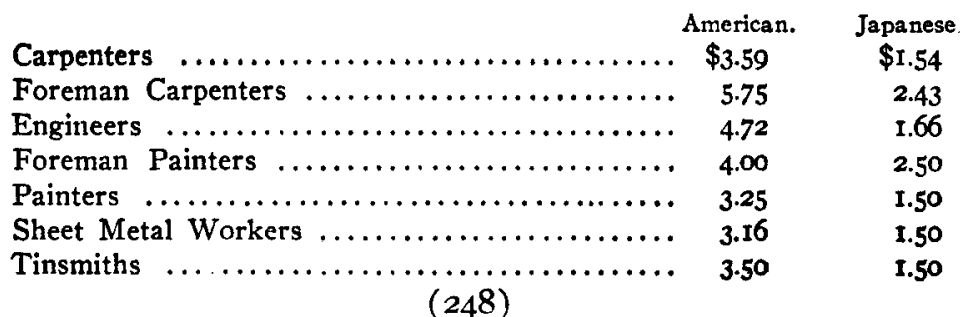


The foregoing table should be convincing evidence that Americans cannot compete with Asiatics and maintain the present standard of living. That the building trades of California have also been invaded will be seen further on.

In several parts of California conditions prevail closely paralleling those existing in Hawaii, and though the number of Asiatics here is but $89,000,{ }^{1}$ against 105,000 in the islands, the thin edge of the wedge has entered and is being driven home. Mercantile and mechanical pursuits have not, however, been invaded to such an extent as in Hawaii, but the danger is a real one, and will be presented in detail later on.

\section{Wages, Hours of Labor and Conditions in San Francisco}

On March 13, 1906, Hon. E. A. Hayes delivered a speech in the House of Representatives, in which he paid particular attention to the competition of Chinese and Japanese in various lines of industry in San Francisco. Since then conditions have grown from bad to worse, until in some lines they have become almost unendurable. The following is compiled from the latest available information:

Seamen: The number of Asiatics sailing between Pacific Coast and trans-Pacific ports is estimated at 3,500 , their wages averaging from $\$ 5.00$ to $\$ 7.50$ United States gold, against $\$ 30.00$ paid to the white seamen for similar services. The Pacific Mail Steamship Company, employing Chinese seamen, is virtually being driven out of business by the competition of Japanese liners, and though operating at a considerable yearly loss, is kept in existence through the patriotism of $\mathrm{Mr}$. Harriman, who refuses to haul down the flag from the only line flying the American flag in the Oriental trade.

Butchers: There are employed in the pork trade 200 Chinese, who work sixteen hours per day, against the ten hours of the white butcher. The Chinese handle about 75 per cent of all the pork slaughtered. In consequence of this competition, the white pork butcher has to work for 24 to 50 per cent less wages than those in other branches of the business. Wages, ${ }^{2}$ - white butchers, $\$ 20$ per week; Chinese, $\$ 35$ per month.

Broom Makers: The Chinese have destroyed competition in this industry by cheap methods and inferior workmanship. The

sJapanese, 55,000 ; Chinese, 30,000; Koreans, 2,000; Hindus, 2,000.

'Ruling wages are given in this compilation.

(249) 
white broom maker works nine hours for $\$ 2.50$ per day. The Chinese work from ten to fourteen hours for $\$ 6.00$ to $\$ 9.00$ per week.

Garment Workers: Including both Chinese and Japanese, there are about $I_{50}$ establishments employing about $\mathrm{I}, 000$ hands working from ten to twelve hours per day for $\$ 4.00$ per week on ladies' wear, to $\$ 50.00$ per month on gentlemen's goods. White workers have a day of nine hours and are paid $\$ 9.00$ to $\$ 20.00$ per week, according to the class of goods.

Laundry Workers: There are in San Francisco over 100 Chinese hand-washing laundries and eighteen modern equipped Japanese steam laundries, employing in the aggregate, with Japanese apprentices, about $\mathrm{I}, 000$ hands. These Asiatic laundries are doing at least five-eighths of the laundry work of the city, and the white worker is being constantly reminded by the employer of the difficulty experienced in competing with Mongolians. Before the advent of the Japanese steam laundry (1905) there were 1,650 white union laundry workers; to-day there are only $\mathrm{I}, 050$. The white laundry worker's time is fifty hours per week, wages $\$ 6.00$ to $\$ 18.00$ per week. The Japanese time is ten to fourteen hours a day, wages $\$ 6.00$ to $\$ 9.00$ per week. The Chinese works as long as he can endure; wages $\$ 3.00$ to $\$ 15.00$ per week.

This competition has caused the establishment of Anti-Jap Laundry Leagues throughout the state, and this action has been met by the Japanese by a still further reduction in their price lists, which now stand at about 50 per cent less than that of the white laundries.

Cooks: The number of Asiatics employed varies according to the season. Chinese, 200 to 300 ; Japanese, 400 to 750 . Hours of labor,-white, from to to thirteen hours per day; Chinese and Japanese, from fourteen to sixteen hours per day. Wages,-white, $\$ 15.00$ to $\$ 25.00$ for six days; Chinese and Japanese, from \$25.00 to $\$ 35.00$ per month, without any day off. The Chinese and Japanese serve meals for ten cents, which entices a certain class of men to extend them their patronage.

In railroad construction throughout the state 200 to 300 Chinese and from 400 to 600 Japanese camp cooks and helpers are employed, the number varying according to the time of the year.

Waiters: The Chinese restaurants, of which there are twenty, employ about I80 of their own countrymen. Of Japanese restau- 
rants there are seventy, in which there are possibly 300 Japanese. In the white restaurants the hours of labor are nine for women, with a wage of $\$ 7.00$, and ten for men, with a wage of $\$ 10.50$. The Chinese average thirteen hours for $\$ 6.00$, and the Japanese fourteen hours for $\$ 5.00$. In boarding houses and saloons there are probably more than 1,000 Japs employed as cooks, porters and maids-of-allwork, to the exclusion of that number of white workers.

Domestics: In this occupation, that of house servant, the Japanese have supplanted the Chinese, as they have supplanted the white domestic. Mr. Walter V. Stafford, who was state labor commissioner, 1902-1906, declared that 5,000 white girls had been robbed of their employment as domestics by Japanese. This was accomplished by several methods: (I) By the student domestic, who gave his services for board and the privilege of going to school; (2) by the organization of Japanese house-cleaning companies, whose members go out by the hour or day, working between times at shoe repairing and other industries, working at a rate and living under conditions to which no self-respecting white girl can submit. The manager of one of the leading female employment agencies recently said: "Any woman who will pay decent wages and treat her help like human beings can get all the girls needed. People have become so accustomed to Orientals that they forget an American girl cannot live like an Asiatic."

In this connection, it may not be amiss to call attention to a statement made by Mr. Hepburn, of Iowa, in reply to a speech by Mr. Hayes upon the Asiatic question:

They are the choice of all the domestics of the gentleman's own state. I do not hesitate to say that 500,000 could be absorbed into the labor field of the United States and not displace a single American.

The trouble is that there are no Americans to displace because, as has been said before, no self-respecting American girl will enter into competition with Mongolians. It is said by some of our philanthropic publicists in California that the American girl is too hard to please; that she expects too much from her employer; but be that as it may, the following excerpts should be sufficient proof that with all her faults the white girl should be preferred to her Asiatic competitor. ${ }^{3}$ M. J. D. Putnam, Chinese Inspector at Los Angeles, Cal., says :

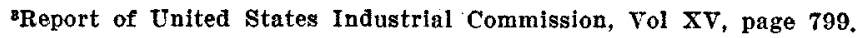

$(25 \mathrm{I})$ 
Those not acquainted with Chinese and their habits and customs, cannot realize the demoralizing effect they have upon the young and rising generation. I venture to say that more girls are ruined by the wily Chinese, as few of them as there are, comparatively, than all other criminal classes combined. Stop and think of the Chinese at the wash tub with a young girl's wardrobe, then as her chambermaid, with his head shaved and his white apron, and with that bland smile on his face, and then turn and look at the ladies who visit their places. Can you believe that the Chinese are more than human? The Chinese as a class are a born set of bribers, gamblers, polygamists and perjurers, and when anyone will show me one actually converted Chinaman among them, then it will be one I have not met. You may have evening mission schools for young Chinese men for young ladies to teach, and you will have no lack of pupils; but take the ladies away and put young men equally capable and religious in their places, and in a short time you will not have a Chinaman attending school.

If in the above you substitute the word "Japanese" for Chinese. and then underline each word, you will still have but a faint conception of the conditions with which the American girl has to compete if she wishes to earn a living by domestic service.

Building Trades: For the purpose of securing information concerning the inroads likely to be made by the Japanese on the building trades, Dr. Carl Saalfield submitted plans, for a house he contemplated building, to Japanese architects and contractors, with the following results: He found that the Japanese have entered into all the thirty-four trades connected with the building of a modern house. He found that they would build a fine house for $\$ 2,000$ lcss than the lowest bid from an American firm. That bid was $\$ 5,800$. The Japanese offered to build it for $\$ 3,800$. They would do everything, from the excavating to the plumbing, gasfitting, painting and decorating,--turning over the keys for a finished house. The doctor, thinking there had been some mistake, went over the plans with them, even to the tile laying, but they stood by their figures. They pay their carpenters $\$ 1.50$ per day and their laborers about 60 per cent less than a white laborer receives. The item for common labor has been figured by the white American at $\$ 700-$ the Japanese figured it at $\$ 25^{\circ}$. In various parts of the state they have done much cement and concrete work, and good work, too, but at a figure which a white man cannot touch and live.

The figures following were compiled from the report of the Twelfth Census, I900, and while we cannot go behind them, we are convinced, through reports emanating from the Treasury Depart(252) 
ment officials, that a large number of Mongolians, both Chinese and Japanese, succeeded in evading the enumerators. Keeping that statement in mind, the following should certainly be of interest:

Mongolians Engaged in the Butlding Industries, igoo.

\begin{tabular}{|c|c|c|c|}
\hline $\begin{array}{l}\text { Occupation. } \\
\text { Carpenters } \ldots \ldots \ldots \ldots \ldots \ldots \ldots \ldots \ldots \ldots \ldots \ldots\end{array}$ & $\begin{array}{l}\text { Chinese. } \\
\quad 4 I 7\end{array}$ & $\begin{array}{l}\text { Japanese. } \\
\quad 666\end{array}$ & $\begin{array}{l}\text { Total. } \\
1,083\end{array}$ \\
\hline Masons (brick and stone) $\ldots \ldots \ldots \ldots \ldots \ldots$ & 4 & 49 & 53 \\
\hline 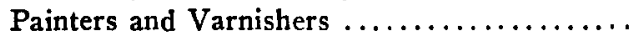 & 105 & 56 & 161 \\
\hline 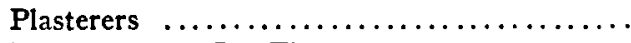 & .. & 4 & 4 \\
\hline 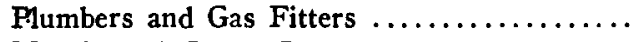 & ... & $I$ & I \\
\hline Marble and Stone Cutters $\ldots \ldots \ldots \ldots \ldots$ & $\cdots$ & 33 & 33 \\
\hline 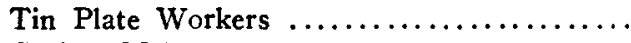 & II6 & 12 & 128 \\
\hline Cabinet Makers $\ldots \ldots \ldots \ldots \ldots \ldots \ldots \ldots$ & I6 & 7 & 23 \\
\hline \multirow[t]{2}{*}{ Saw and Planing Mill Workers } & 76 & 165 & $24 \mathrm{I}$ \\
\hline & 734 & 993 & 1,727 \\
\hline
\end{tabular}

It is thus seen that there were 734 Chinese and 993 Japanese building mechanics in 1900 , but how many of them were in California we have no means of finding out. We do know, however, that since 1900 over 50,000 Japanese have come to the mainland of the United States from the Territory of Hawaii, and that the Japanese population of California has increased over 600 per cent; and it would be the height of folly to assume that there was not more than a fair sprinkling of building mechanics among them. We know further that during the years 1901 to 1907 , both inclusive, 109,406 Japanese entered the United States through legal channels, and of that number 4,446 were skilled mechanics. It is not reasonable to believe that they will be content to work as field laborers and domestics when the opportunity is afforded them to invade the building industries.

Farm Labor: The employment of Japanese upon the farms of California is a measure which, though apparently necessary at one time, is now a source of regret to those responsible for their introduction.

In 1895 a labor contractor in Honolulu offered to place 30,000 Japanese laborers in the agricultural districts of California, who would work for $\$ 12.00$ per month and board themselves. This proposition was taken up with avidity by the farmers, who were always short of help in the harvest season, and the records of the steamship companies show that many thousands came. In a very 
short while the white farm laborers were driven to the large cities, and the Japanese had the field of agriculture to themselves. It was not long before the farmers discovered that they had created a "Frankenstein." Instead of having "cheap" labor, they soon had to pay the Japanese more wages than they formerly paid the white workingmen. By working in gangs under a head man, and by combination through the various Japanese associations, they have advanced their wages to $\$ 2.00$ a day and upward. In many cases, the farmer becoming discouraged by the continual raids upon his pocket, leased his ranch to Japanese on shares, to be again outwitted by his Oriental "friends." The last resort was to lease or sell outright, until the Japanese own and lease in the aggregate some I50,000 acres of the most fertile land in the state. The result is that to-day the potato crop of the state is controlled by George Shima, the "Potato King," who compels us to pay five cents per pound for potatoes at retail.

In Southern California the celery crop and other vegetables are controlled by Japanese, the white growers being helpless against them. In the Santa Clara Valley, one of the most beautiful parts of the state, the berry crop is almost entirely in the hands of the Japanese.

Recently, however, the Farmers' Educational and Co-operative Society has taken the matter in hand, and is seeking the co-operation of organized labor to aid in marketing farm products raised and packed entirely by white labor. The following excerpts from the Twelfth Biennial Report of the California Bureau of Labor Statistics illustrates in a vivid manner the conditions existing in several of the districts dominated by the Japanese:

Watsonville--Men of standing in the community who employ Japanese and have no race prejudice, apparently, and who are distinctly opposed to labor unions, largely on account of the opposition of the latter to Orientals, declare the Japanese dishonest and inferior in this regard to the Chinese. When the Japanese arrived in the Pajaro Valley they were welcomed by the merchants; to-day the merchants bitterly complain that the Japanese have become their very close competitors. They run restaurants, barbershops and ready-made clothing stores in the City of Watsonville and operate busses and delivery wagons in the adjacent territory. One bank positively refuses to open any account with the Japanese because of their absolute dishonesty, the same bank welcoming business from the Chinese. The local postmaster places the Jap in a class by himself, and will not cash his money orders without other evidence than the possession of the order, and there is a large postoffice money 
order business with the Japanese on account of the fact that certain banks decline to do business with them.

Vacaville.-The Japanese came to Vaca Valley, Solano County, about eighteen years ago and commenced working for very small wages. Their number increased until they not only displaced about all the white labor, but almost entirely ran out the Chinese. They then began to rent orchards, paying cash in advance, thereby undermining the Chinese, who generally paid with a share of the crops. The Jap outbid the Chinaman until he ceased to be a factor. This condition developed until the Japanese control, by lease and ownership, half of the fruit farms in the valley at this time.

Latterly their handling of leased ranches has been less satisfactory. They cultivate indifferently, or for immediate results, to the serious detriment of the property. Prior to the advent of the Japanese, Vaca Valley was renowned for its orchards, which attracted wide attention, especially on account of the superior methods of pruning and cultivating. To-day there can be no boasting in this respect. Large shipping firms give the Japanese credit and backing, and aid them in obtaining leases, etc., on account of their ability to obtain labor in the fruit season. The white rancher can scarcely obtain such aid, on account of his lack of assurance of sufficient help. In other words, the Japanese have the best organization.

It is generally conceded that 90 per cent of all the people met, walking or driving on all the country roads around Vacaville, are Japanese. One of the prominent fruit growers and shippers in the valley estimates the fruit orchards of Vaca Valley and adjoining foothills at 15,000 acres, more than half of which are in the hands of Japanese lessees, or owners, principally leased. He declared the Jap is an expert at drawing all the vitality out of the land and the trees. Land values have shrunk one-third in the past fifteen years.

The Japanese stores, of which there are six in Vacaville, are doing more than 50 per cent of the general merchandise business of the town, and 90 per cent of the farm supply business.

Fresno.-In Fresno, as at other points, it is generally conceded that the Jap is merciless when he has his employer at a disadvantage; that he will work cheaply until all competition is eliminated, and then strike for higher wages, totally disregarding any agreement or contract.

There is no place in the state where the problem is so grave, from the fact that the raisin territory (and Fresno is the greatest producer of raisins on the planet) depends almost entirely on the Orientals. Last year over 4,000 cars of raisins were shipped from Fresno. The more intelligent citizens realize the gravity of the situation both from the economic and racial sides. Similar conditions in a lesser degree exist in the different berry and sugar beet sections of the state. The general persistency with which the Japanese are breaking into many industries, their frugality, their ambition and their lack of business morality, render them more formidable than the Chinese.

It is astonishing that in the light of this evidence so many public men, in and out of Congress, declare that the labor necessi(255) 
ties of the Pacific Coast demand the presence of these Asiatics. They say that our fruit orchards, mines and seed farms cannot be worked without them. It were better that they never be developed than that our white laborers be degraded and driven from the soil. The same arguments were used a century and more ago, to justify the importation of African labor. I assert, most emphatically, that there is no demand for labor on the Pacific Coast that cannot be fully met with white laborers if conditions are made such that they will wish to come and remain here. As it is now, no self-respecting white laborer will work beside the Mongolian upon any terms. The proposition, whether we shall have white or yellow labor on the Pacific Coast, must soon be settled, for we cannot have both. If the Mongolian is permitted to occupy the land, the white laborer from east of the Rockies will not come here-he will shun California as he would a pestilence. And who can blame him?

Note.-The authorities consulted for this paper were:

Hawaii: Third Report on Hawaii, published as Bulletin 66 of U. S. Bureau of Labor, September, I906.

California: Reports of California, Bureau of Labor Statistics, 1898-1908.

Report of U. S. Industrial Commission, Vol. XV.

Correspondence of County Officials of California and the voluminous files of the Asiatic Exclusion League of San Francisco. 